\title{
The Effect of Temperature on Nitrate and Phosphate Uptake from Synthetic Wastewater by Selected Bacteria Species
}

\author{
O. B. Akpor ${ }^{1^{*}}$, T. D. Olaolu ${ }^{2}$ and E. C. Okolie ${ }^{1}$ \\ ${ }^{1}$ Microbiology Unit, Department of Biological Sciences, Landmark University, Omu Aran, \\ Kwara State, Nigeria. \\ ${ }^{2}$ Biochemistry Unit, Department of Biological Sciences, Landmark University, Omu Aran, \\ Kwara State, Nigeria.
}

\section{Authors' contributions}

This work was carried out in collaboration between all authors. Author OBA designed the study, carried out the laboratory analysis, performed the statistical analysis and wrote the first draft of the manuscript. Author TDO carried out the laboratory analysis, performed the statistical analysis, carried out the analysis of results and proof read the first draft manuscript and author ECO managed the literature search, carried out the laboratory analysis and proof read the first draft manuscript All authors read and approved the final manuscript.

Original Research Article

Received 14 ${ }^{\text {th }}$ August 2013

Accepted $27^{\text {th }}$ October 2013

Published $27^{\text {th }}$ December 2013

\section{ABSTRACT}

Aim: The aim of this study was to ascertain the effect of temperature on nutrient uptake ability of four bacterial species.

Methodology: A total of four bacterial species (Klebsiella sp., Pseudomonas sp., Lysinibacillus sp. and Staphylococcus sp.) were used for the study. The media used for the investigation was synthetic wastewater. Four different temperatures $\left(25^{\circ} \mathrm{C}, 30^{\circ} \mathrm{C}, 35^{\circ} \mathrm{C}\right.$ and $40^{\circ} \mathrm{C}$ ) were used for the investigation. The study was carried out under shake flasks conditions. Immediate after inoculation with the respective test bacterial species and every $24 \mathrm{~h}$ for a $96 \mathrm{~h}$ incubation time, aliquot wastewater samples were removed from the flasks for the estimation of total phosphate, nitrate, $\mathrm{pH}$ and growth rate, using standard procedures.

Results: The results revealed phosphate and nitrate removal ranges of $10.84 \%$ to $55.55 \%$ and $90.67 \%$ to $97.27 \%$, respectively in the presence of the Klebsiella sp. In the presence of the Pseudomonas sp, Lysinibacillus sp. and Staphylococcus sp., phosphate removals 
ranges of $0.36 \%$ to $46.98 \%, 11.89 \%$ to $50.80 \%$ and $2.74 \%$ to $51.21 \%$ were observed, respectively. For nitrate concentrations, removal levels that ranged from $2.19 \%$ to $92.95 \%$, $0.97 \%$ to $23.12 \%$ and $7.56 \%$ to $91.66 \%$ were observed in the presence of Pseudomonas $\mathrm{sp}$, Lysinibacillu ssp. and Staphylococcus sp., respectively. All the test bacterial species showed some measure of efficiency in phosphate removal. For nitrate removal, the Lysinibacillus sp. did not exhibit remarkable nitrate removal ability at any of the temperatures. In addition, the optimum temperatures for phosphate removals were observed to be $30^{\circ} \mathrm{C}$ to $40^{\circ} \mathrm{C}$ for the Klebsiella sp. and Pseudomonas sp; and $30^{\circ} \mathrm{C}$ to $35^{\circ} \mathrm{C}$ for the Lysinibacillus sp. and Staphylococcus sp. For nitrate removal, optimum temperatures for removal were observed to be $25^{\circ} \mathrm{C}$ to $40^{\circ} \mathrm{C}$, for the Klebsiella sp and $25^{\circ} \mathrm{C}$ to $35^{\circ} \mathrm{C}$, for the Pseudomonas sp. and Staphylococcus sp.

Conclusion: The study was able to reveal the optimum temperatures for phosphate and nitrate uptake in synthetic wastewater by the test bacterial species.

Keywords: Bacterial species; nutrient uptake; wastewater.

\section{INTRODUCTION}

It is reported that nutrient-linked causes are the basis for approximately $25 \%$ of all water body impairments. Some of these impairments include oxygen depletion, algal growth, ammonia, harmful algal blooms, biological integrity, and turbidity [1]. Although phosphorus (used in the cells mainly for production of phospholipids, ATP and nucleic acid) and nitrogen (second most important nutrient after carbon, and may comprise more than $10 \%$ of a biomass) are important nutrients for living organisms, their presence in excess amount in receiving water bodies is the leading cause of eutrophication $[2,3]$.

The eutrophication of receiving water bodies is due to the presence of nutrients in excessive amounts. Eutrophication could lead to the depletion of oxygen, death of aquatic life and other hazards to human population and the environment [4,5]. Owing to the negative impacts of eutrophication, there is the need to treat wastewater effluents to reduce nutrient limits that complies with standards set by regulatory bodies [1].

The most commonly used treatment methods used in the elimination of phosphorus and nitrogen from polluted wastewater are chemical and biological [6]. Because of its simplicity, economy and various other environmental benefits, biological removal processes is advocated over chemical methods in recent [7]. Chemical methods are also not encouraged because of the high cost of the chemical process and volume of sludge produced during treatment [8]. Over the few decades, biological nutrient removal processes have been employed for the removal of total nitrogen and phosphorus from wastewater by using different microorganisms under different environmental conditions [9].

Although other microorganisms such as fungi, protozoa and microalgae have been implicated in nutrient removal from wastewater, nutrient removal in wastewater treatment systems have been attributed mainly to bacteria [10]. Bacteria are known to be of great numerical importance in the activated sludge system and are responsible for the stabilization of wastes coming into a treatment plant. A number of studies have revealed the involvement and efficiency of bacteria in nutrient removal from wastewater. A number of bacteria, such as Pseudomonas, Klebsiella, Acinetobacter, Escherichia coli, Bacillus and Enterobacter have 
been reported by several investigators as important in biological nutrient removal $[5,11,12$, $13,14]$.

In biological nutrient removal systems, an optimum temperature condition is essential for the efficiency of the treatment processes. This is because temperature is known to have influence on water chemistry and biological activities. Also, microbial growth is known to be strongly influenced by temperature, with optimal temperatures for microbial activity indicated to range from $20-25^{\circ} \mathrm{C}$ [15]. This investigation was therefore aimed at ascertaining the role of temperature in nutrient uptake abilities of four bacteria species Pseudomonas sp., Klebsiellasp., Lysinibacillussp. and Staphylococcus sp.

\section{MATERIAL AND METHODS}

A total of four bacterial species (Pseudomonas sp., Klebsiell asp, Lysinibacillu ssp. and Staphylococcus sp.) were used for this study. The isolates were obtained from the Department of Microbiology, Ekiti State Univesrity, Ado Ekiti, Ekiti State, Nigeria. Prior use, the isolates were maintained in nutrient agar slants and stored at $4^{\circ} \mathrm{C}$ till needed. Before usage, all isolates were first streaked in nutrient agar plates to ascertain their purity.

For nutrient removal studies, the isolates were cultured in nutrient broth and incubated for 18 $\mathrm{h}$ to $24 \mathrm{~h}$ in an incubator at $37^{\circ} \mathrm{C}$. The population of the bacteria in the nutrient broth was estimated, using standard plating procedures [17]. For this study, the population of cells that were used for inoculation was $2.91 \times 10^{8} \mathrm{cfu} / \mathrm{mL}, 6.31 \times 10^{8} \mathrm{cfu} / \mathrm{mL}, 1.75 \times 10^{8} \mathrm{cfu} / \mathrm{mL}$ and $7.1 \times 10^{8} \mathrm{cfu} / \mathrm{mL}$ for the Klebsiellasp., Pseudomonas sp, Lysinibacillussp. and Staphylococcus $\mathrm{sp}$, respectively.

For the nutrient removal studies, the media that was used was synthetic wastewater. The synthetic wastewater was composed of $5.0 \mathrm{~g} / \mathrm{L}$ sodium acetate, $0.5 \mathrm{~g} / \mathrm{L}$ magnesium sulphate, $0.5 \mathrm{~g} / \mathrm{L}$ potassium nitrate, $0.5 \mathrm{~g} / \mathrm{L}$ potassium dihydrogen phosphate, $1.0 \mathrm{~g} / \mathrm{L}$ meat extract, $1.0 \mathrm{~g} / \mathrm{L}$ peptone and $0.5 \mathrm{~g} / \mathrm{L}$ sodium chloride. The different components of the media were weighed and dissolved separately in small quantities of deionised water before combining everything together as one media and making up to the desired mark.

Initially, the media was dispensed in $200 \mathrm{~mL}$ quantity in $250 \mathrm{~mL}$ Erlenmeyer flasks, which were plugged with non-adsorbent cotton wool and sterilised in an autoclave at $121{ }^{\circ} \mathrm{C}$ at $2.07 \mathrm{~kg} / \mathrm{cm}^{2}$ for $15 \mathrm{~min}$. After sterilisation, aliquot samples from each of the flasks were taken and cultured in nutrient agar plates and then incubated. This was to ascertain the efficiency of the sterilisation conditions. Only flasks whose samples did not show any growth in the culture plates were used for the nutrient removal studies.

After sterilisation, a known population of the respective bacterial species were inoculated into each flask and incubated at the required temperatures for the study. Just immediately after inoculation and every $24 \mathrm{~h}$ for $96 \mathrm{~h}$, aliquot samples of $20 \mathrm{~mL}$ were taken from each flask for the determination of the phosphate and nitrate concentrations, growth rate and $\mathrm{pH}$, using standard procedures [16]. Phosphate, nitrate and $\mathrm{pH}$ were determined using the ascorbic acid method, salicylate method and $\mathrm{pH}$ meter, respectively.

In this study, all reagents used were of analytical grade. Also, all experimental setups were carried out in triplicate. 
Generally, all statistical analysis was carried out using the PAST (paleontological statistics software package for education and data analysis [17]. The test for the comparison of means was done using the one-way analysis of variance (ANOVA). All statistics were run at probability level of 0.05 .

\section{RESULTS AND DISCUSSION}

In the presence of the Klebsiellasp., although there were decreases in phosphate concentration in the wastewater at the different temperatures, significant decreases were only observed at incubation temperatures of $30^{\circ} \mathrm{C}, 35^{\circ} \mathrm{C}$ and $40^{\circ} \mathrm{C}$. The significant decreases were observed from $48 \mathrm{~h}$ to the end of incubation. At the expiration of the $96 \mathrm{~h}$ incubation period, phosphate concentration in the wastewater was observed to decrease from an initial value of $191.6 \mathrm{mg} / \mathrm{L}$ to $170.8 \mathrm{mg} / \mathrm{L}$ at $25^{\circ} \mathrm{C}, 77.1 \mathrm{mg} / \mathrm{L}$ at $30^{\circ} \mathrm{C}, 83.0 \mathrm{mg} / \mathrm{L}$ for $35^{\circ} \mathrm{C}$ and 85.2 $\mathrm{mg} / \mathrm{L}$, at $40^{\circ} \mathrm{C}$ (Fig. 1). The decreases in phosphate concentrations at $30^{\circ} \mathrm{C}, 35^{\circ} \mathrm{C}$ and $40^{\circ} \mathrm{C}$ were observed to be significantly different from that at $25^{\circ} \mathrm{C}(P \leq 0.05)$.

For nitrate concentration in the presence of the Klebsiellasp., significant decreases were observed from the $24 \mathrm{~h}$ of incubation at incubation of concentration $25^{\circ} \mathrm{C}, 30^{\circ} \mathrm{C}$ and $35^{\circ} \mathrm{C}$. However at the $96 \mathrm{~h}$ incubation period, significant decreases in concentration were observed at the different temperatures. From an initial concentration of $256.3 \mathrm{mg} / \mathrm{L}$, nitrate levels were observed after $96 \mathrm{~h}$ to be $23.9 \mathrm{mg} / \mathrm{L}, 11.2 \mathrm{mg} / \mathrm{L}, 7.0 \mathrm{mg} / \mathrm{L}$ and $18.4 \mathrm{mg} / \mathrm{L}$, at $25^{\circ} \mathrm{C}, 30^{\circ} \mathrm{C}, 35$ ${ }^{\circ} \mathrm{C}$ and $40^{\circ} \mathrm{C}$, respectively (Fig. 2). Generally, the decrease in nitrate concentration in the presence of the Klebsiellasp. was not observed to be significantly different at the different incubation temperatures $(P \leq 0.05)$.

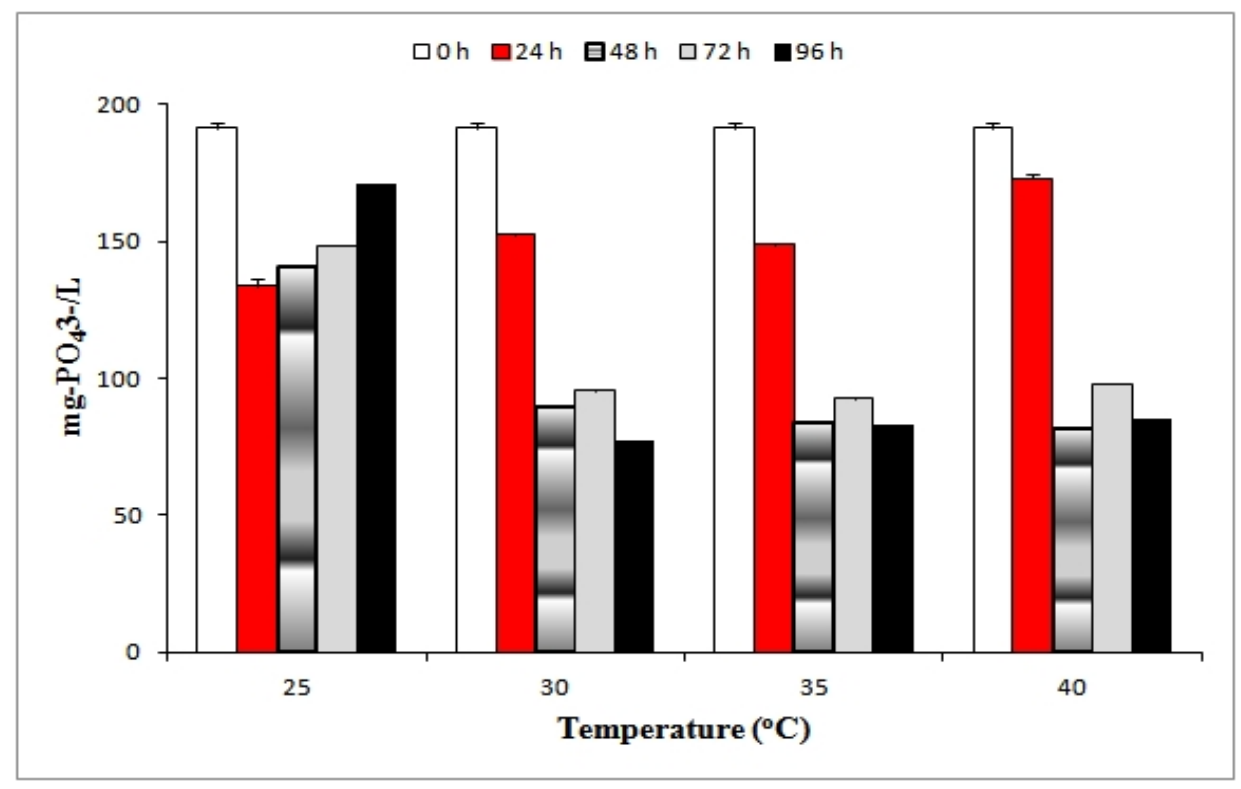

Fig. 1. Trend in phosphate removal at the different temperatures in presence of the Klebsiella sp 


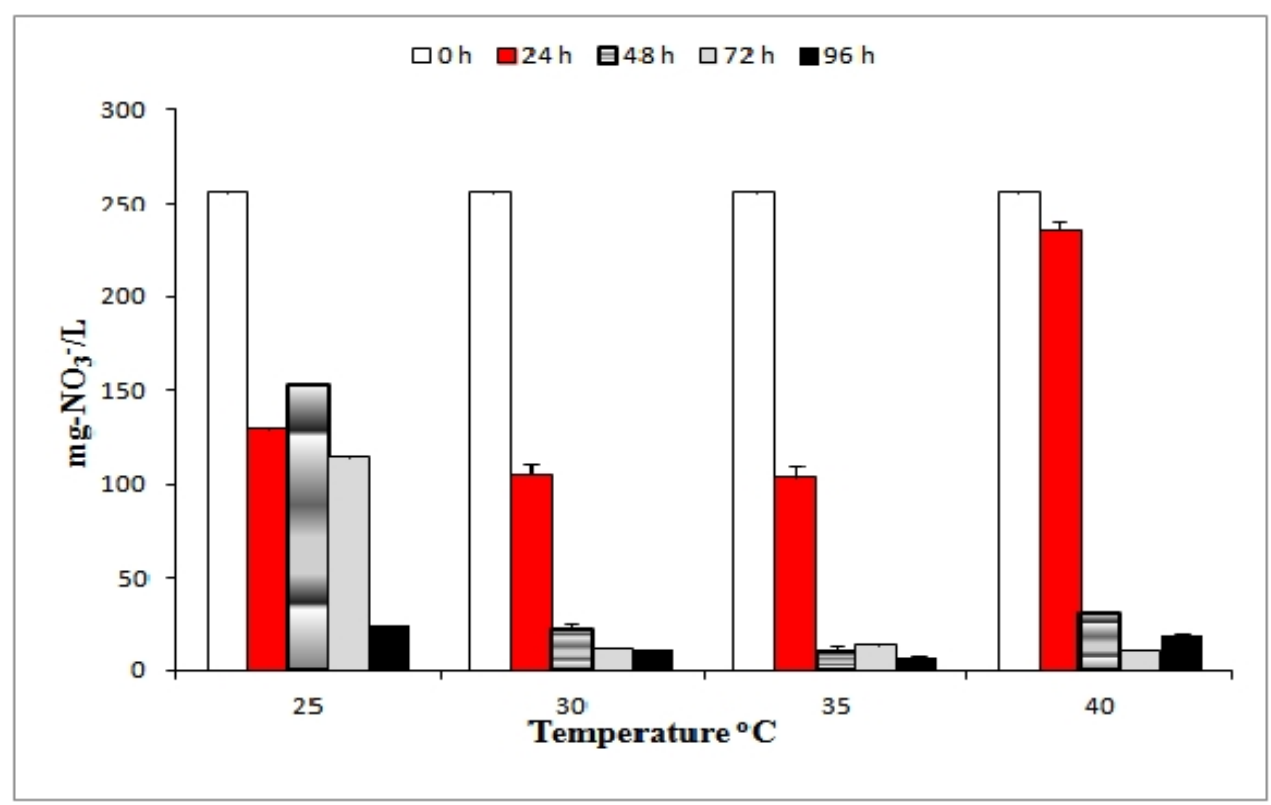

Fig. 2. Trend in nitrate removal at the different temperatures in presence of the Klebsiella sp.

As shown in figure 5, in the presence of the Lysinibacillus sp., remarkable decreases in phosphate concentrations were only observed at temperature of $30^{\circ} \mathrm{C}$ and $35^{\circ} \mathrm{C}$. No remarkable decreases were observed at temperatures of $25^{\circ} \mathrm{C}$ and $40^{\circ} \mathrm{C}$. At $30^{\circ} \mathrm{C}$ and $35^{\circ} \mathrm{C}$, remarkable decreases were observed from $48 \mathrm{~h}$ till the end of the incubation period. From an intial concentration of $191.5 \mathrm{mg} / \mathrm{L}$, phosphate concentrations were observed to be 191.6 $\mathrm{mg} / \mathrm{L}$ at $25^{\circ} \mathrm{C}, 94.3 \mathrm{mg} / \mathrm{L}$ at $30^{\circ} \mathrm{C}, 104.9 \mathrm{mg} / \mathrm{L}$, at $35^{\circ} \mathrm{C}$ and $168.8 \mathrm{mg} / \mathrm{L}$, at $40^{\circ} \mathrm{C}$ (Fig. 3). The phosphate levels at temperatures of $30^{\circ} \mathrm{C}$ and $35^{\circ} \mathrm{C}$ were observed to be significantly lower than those at $25^{\circ} \mathrm{C}$ and $40^{\circ} \mathrm{C}(\mathrm{P} \leq 0.05)$.

For nitrate removal in presence of the Lysinibacillussp., no significant decreases in concentration were observed at the different temperatures. Slight decreases in concentration were however observed $25^{\circ} \mathrm{C}$. From an initial concentration of $256.3 \mathrm{mg} / \mathrm{L}$, nitrate levels after the $96 \mathrm{~h}$ incubation period were found to be $197.0 \mathrm{mg} / \mathrm{L}, 252.9 \mathrm{mg} / \mathrm{L}, 239.2 \mathrm{mg} / \mathrm{L}$ and $249.9 \mathrm{mg} / \mathrm{L}$, at $25^{\circ} \mathrm{C}, 30^{\circ} \mathrm{C}, 35^{\circ} \mathrm{C}$ and $40^{\circ} \mathrm{C}$, respectively (Fig. 4). Generally, no significant differences in nitrate levels were observed between the different temperatures $(P \leq 0.05)$. 


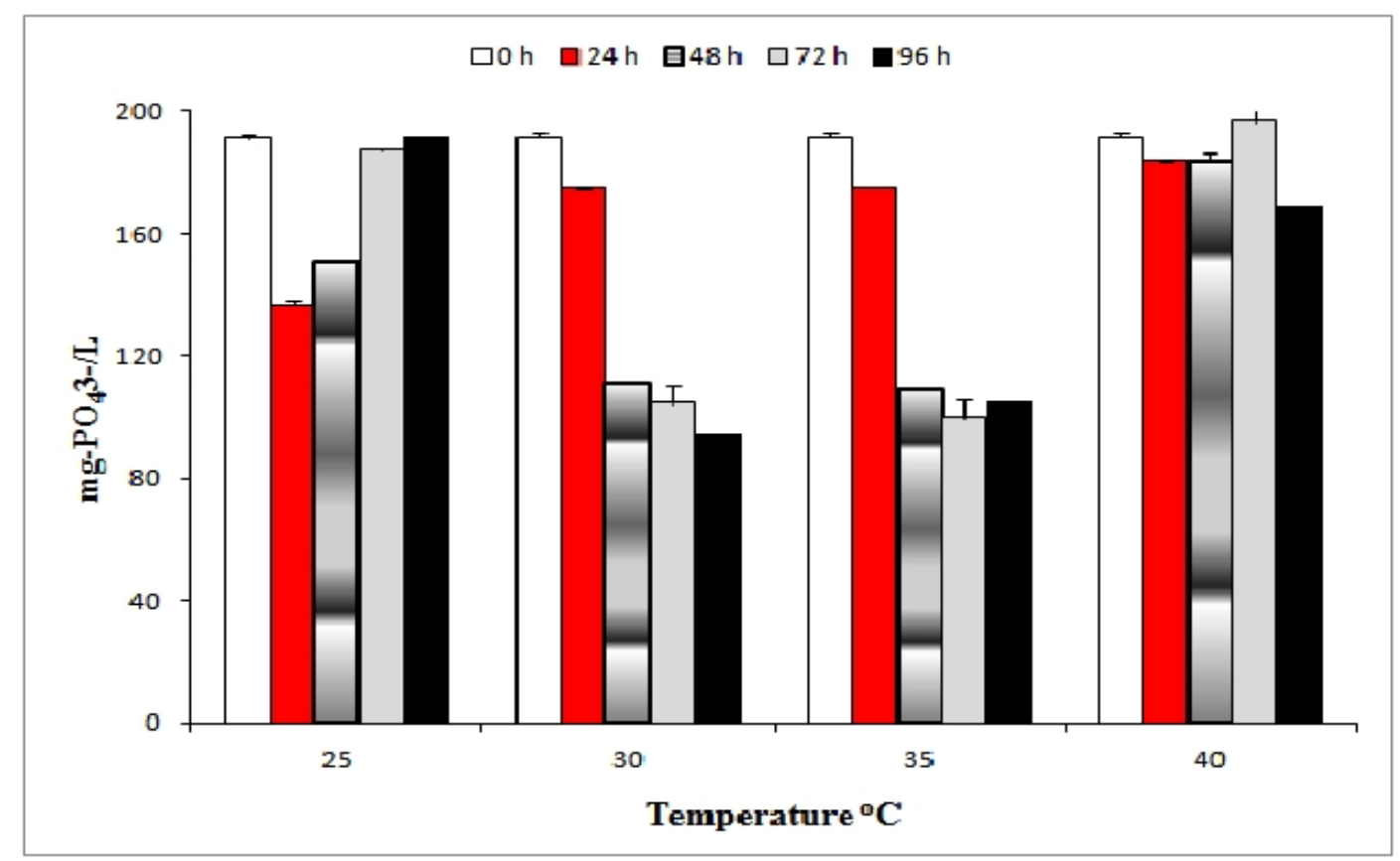

Fig. 3. Trend in phosphate removal at the different temperatures in presence of the Lysinibacillus sp.

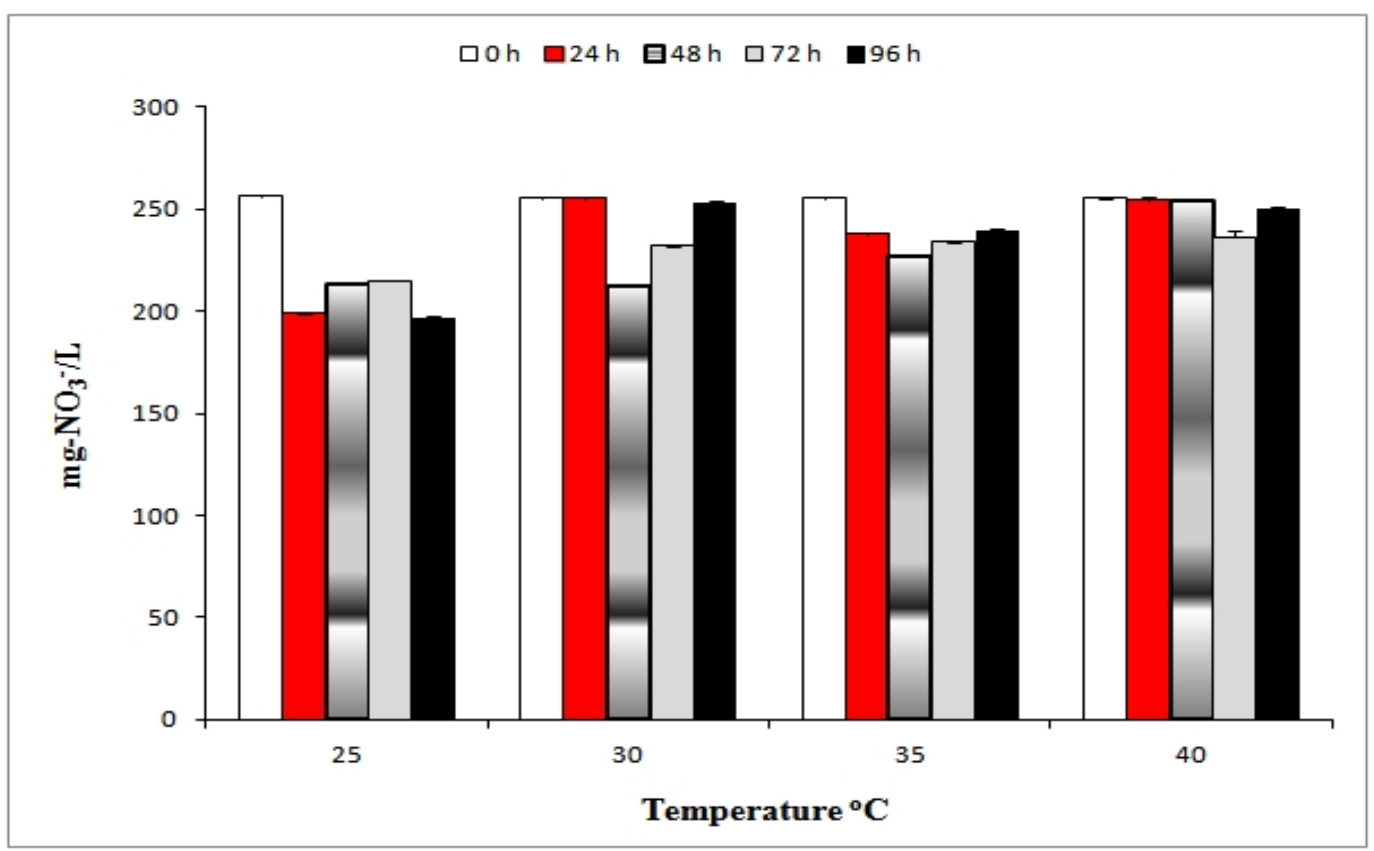

Fig. 4. Trend in nitrate removal at the different temperatures in presence of the Lysinibacillus sp. 
When the Pseudomonas sp. was used for inoculation, only small decreases in phosphate concentration were observed between $24 \mathrm{~h}$ and $72 \mathrm{~h}$ incubation, after which there was a sharp increase with time at $25^{\circ} \mathrm{C}$. At incubation temperatures of $30^{\circ} \mathrm{C}, 35^{\circ} \mathrm{C}$ and $40^{\circ} \mathrm{C}$, although no decreases in concentrations were observed within the first $24 \mathrm{~h}$ of incubation, remarkable decreases were observed from $48 \mathrm{~h}$ to the end of incubation. At the expiration of the incubation periods, phosphate levels at the different temperatures were found to be $190.8 \mathrm{mg} / \mathrm{L}, 78.6 \mathrm{mg} / \mathrm{L}, 88.5 \mathrm{mg} / \mathrm{L}$ and $101.1 \mathrm{mg} / \mathrm{L}$, at incubation temperatures of $25^{\circ} \mathrm{C}, 30$ ${ }^{\circ} \mathrm{C}, 35^{\circ} \mathrm{C}$ and $40^{\circ} \mathrm{C}$, respectively (Fig. 5). At the expiration of the incubation period, phosphate levels at temperatures of $30^{\circ} \mathrm{C}, 35^{\circ} \mathrm{C}$ and $40^{\circ} \mathrm{C}$ were observed to be significantly lower than levels at $25^{\circ} \mathrm{C}(P \leq 0.05)$.

In the case of nitrate concentration in presence of the Pseudomonas sp., significant removals were observed from $24 \mathrm{~h}$ to the end of incubation at temperatures of $25^{\circ} \mathrm{C}, 30^{\circ} \mathrm{C}$, and $35^{\circ} \mathrm{C}$. At $40^{\circ} \mathrm{C}$, no remarkable decreases in concentration were observed. From an initial concentration of $267.70 \mathrm{mg} / \mathrm{L}$, nitrate concentrations after the end of the incubation period were observed to be $11.5 \mathrm{mg} / \mathrm{L}, 20.8 \mathrm{mg} / \mathrm{L}, 18.6 \mathrm{mg} / \mathrm{L}$ and $261.0 \mathrm{mg} / \mathrm{L}$, at temperature of $25^{\circ} \mathrm{C}, 30^{\circ} \mathrm{C}, 35^{\circ} \mathrm{C}$ and $40^{\circ} \mathrm{C}$, respectively (Fig. 6). At the end of incubation, nitrate concentrations at $25^{\circ} \mathrm{C}, 30^{\circ} \mathrm{C}$ and $35^{\circ} \mathrm{C}$ were observed to be significantly lower than concentration at $40^{\circ} \mathrm{C}(\mathrm{P} \leq 0.05)$.

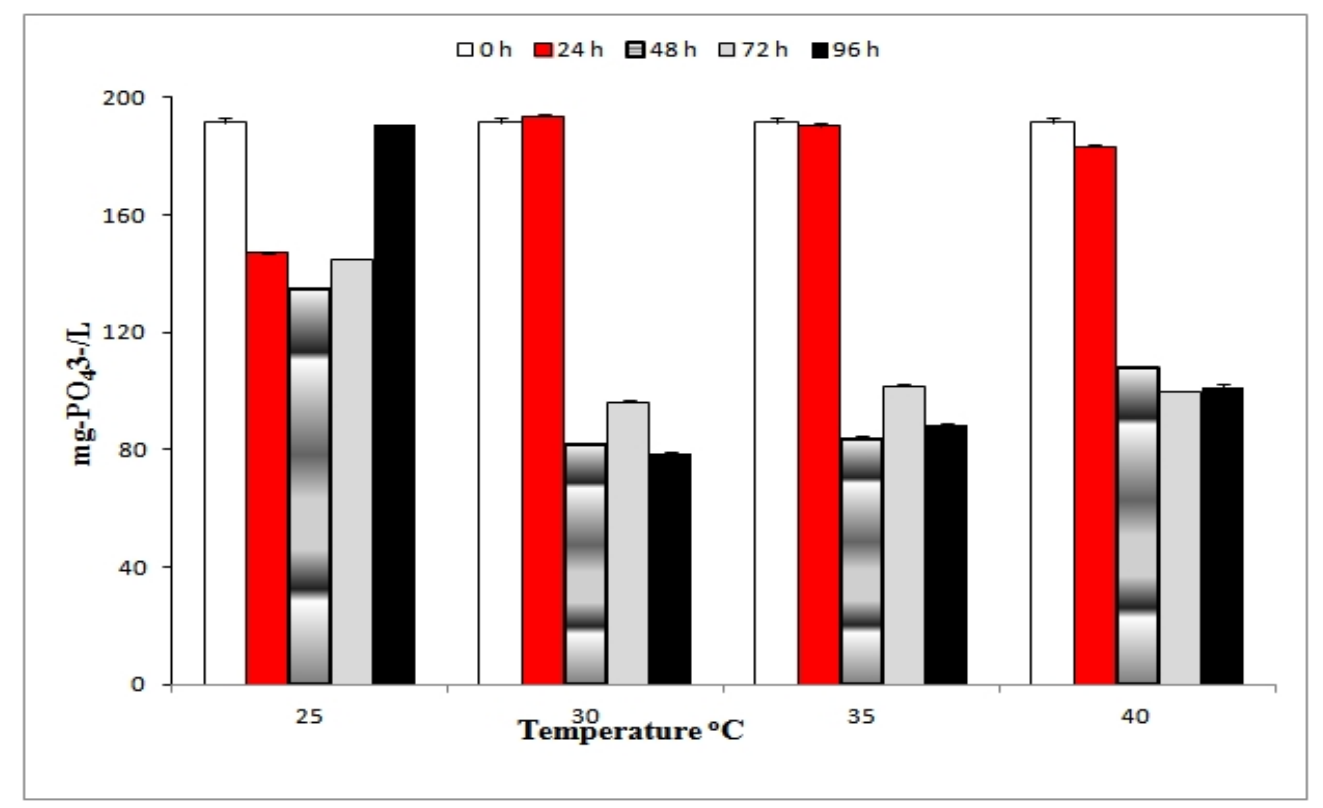

Fig. 5. Trend in phosphate removal at the different temperatures in presence of the Pseudomonas sp. 


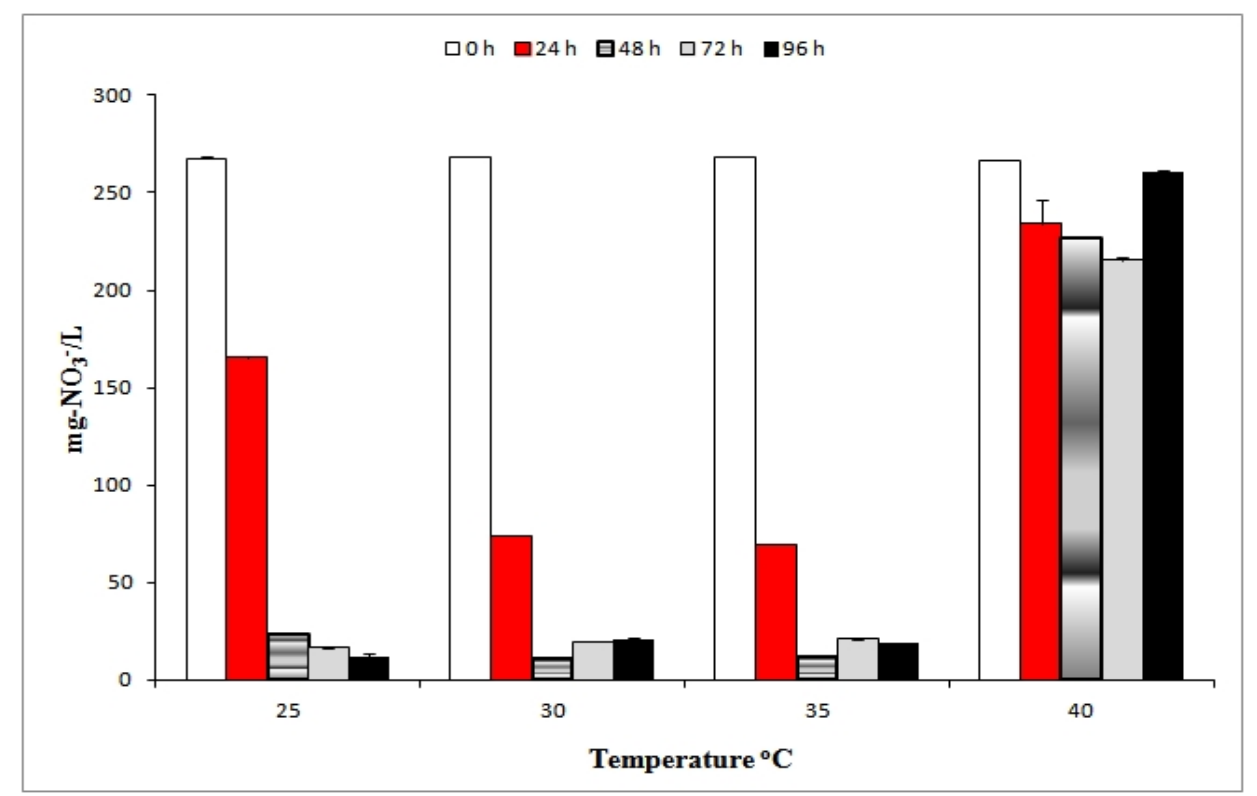

Fig. 6. Trend in nitrate removal at the different temperatures in presence of the Pseudomonas sp.

In the presence of the Staphylococcus sp., significant phosphate removals were only observed at $30^{\circ} \mathrm{C}$ and $35^{\circ} \mathrm{C}$. At $25^{\circ} \mathrm{C}$, slight decreases in concentration were observed between $24 \mathrm{~h}$ and $48 \mathrm{~h}$. At $40^{\circ} \mathrm{C}$, no notable decreases in concentration were observed within the first $72 \mathrm{~h}$ of incubation. From an initial concentration of $191.50 \mathrm{mg} / \mathrm{L}$, phosphate levels after the $96 \mathrm{~h}$ incubation period were found to be $186.2 \mathrm{mg} / \mathrm{L}$ at $25^{\circ} \mathrm{C}, 93.4 \mathrm{mg} / \mathrm{L}$ at 30 ${ }^{\circ} \mathrm{C}, 94.6 \mathrm{mg} / \mathrm{L}$ at $35^{\circ} \mathrm{C}$ and $121.0 \mathrm{mg} / \mathrm{L}$ at $40^{\circ} \mathrm{C}$ (Fig. 7). The phosphate decreases at temperatures of $30^{\circ} \mathrm{C}$ and $35^{\circ} \mathrm{C}$ were observed to be significantly lower than levels at $25^{\circ} \mathrm{C}$ and $40^{\circ} \mathrm{C}(P \leq 0.05)$.

For nitrate removals in presence of the Staphylococcus sp were observed to decrease significantly from $48 \mathrm{~h}$ to the end of the incubation period at incubation temperatures of 25 ${ }^{\circ} \mathrm{C}, 30^{\circ} \mathrm{C}$ and $35^{\circ} \mathrm{C}$. At $40^{\circ} \mathrm{C}$, no remarkable decreases in nitrate levels were observed with incubation time. At end of the incubation period, nitrate levels were found to decrease from initial levels of $256.3 \mathrm{mg} / \mathrm{L}$ to $33.9 \mathrm{mg} / \mathrm{L}, 21.4 \mathrm{mg} / \mathrm{L}$ and $27.6 \mathrm{mg} / \mathrm{L}$ and $236.1 \mathrm{mg} / \mathrm{L}$ at temperatures of $25^{\circ} \mathrm{C}, 30^{\circ} \mathrm{C}, 35^{\circ} \mathrm{C}$ and $40^{\circ} \mathrm{C}$, respectively (Fig. 8). 


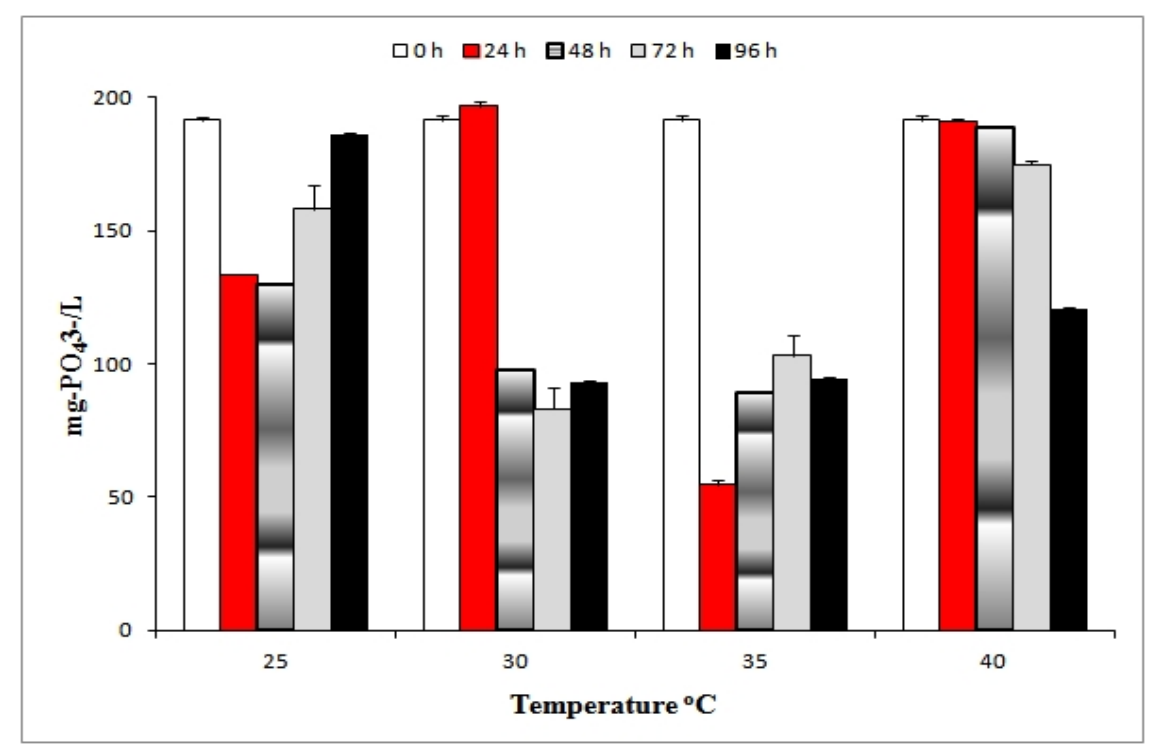

Fig. 7. Trend in phosphate removal at the different temperatures in presence of the Staphylococcus sp.

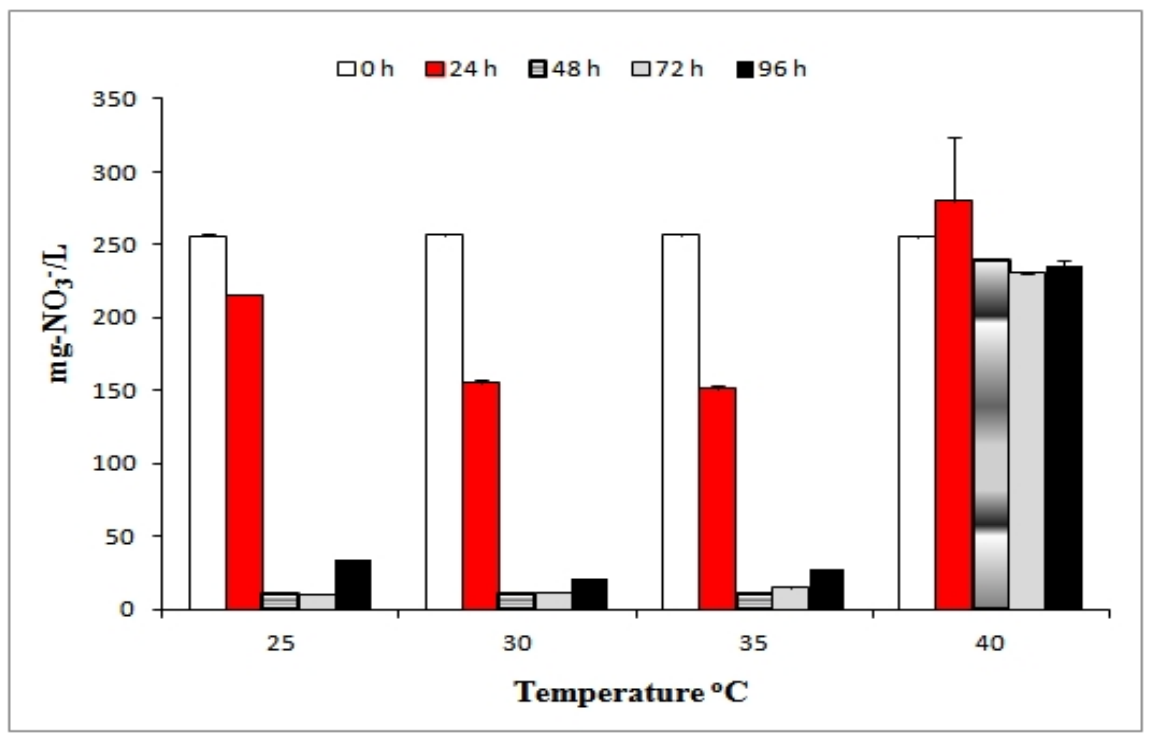

Fig. 8. Trend in nitrate removal at the different temperatures in presence of the Staphylococcus sp.

With respect to percentage nutrient removal at the different temperatures, maximum phosphate and nitrate removals of $59.8 \%$ and $97.3 \%$ were observed at $30{ }^{\circ} \mathrm{C}$ and $35{ }^{\circ} \mathrm{C}$, respectively in presence of the Klebsiella sp. In the presence of the Pseudomonas sp., maximum phosphate and nitrate removals of $59.0 \%$ and $92.8 \%$ were observed at $30{ }^{\circ} \mathrm{C}$ and $35{ }^{\circ} \mathrm{C}$, respectively. Also, the highest phosphate removal levels of $50.8 \%$ and $51.2 \%$ were observed at $30^{\circ} \mathrm{C}$ in presence of the Lysinibacillu ssp. and Staphylococcus sp., respectively. 
For nitrate removal, the highest levels were observed at $25^{\circ} \mathrm{C}$ and $35^{\circ} \mathrm{C}$ in the presence of the Lysinibacillu ssp. and Staphylococcus sp., respectively (Table 1).

Table 1. Percentage change in phosphate and nitrate concentrations at the different temperatures in presence of the test bacterial species

\begin{tabular}{|c|c|c|c|c|c|c|}
\hline Temperature & $\begin{array}{l}\text { Initial } \\
\text { (mg/L) }\end{array}$ & $\begin{array}{l}\begin{array}{l}\text { Final } \\
\text { (mg/L) }\end{array} \\
\end{array}$ & $\begin{array}{l}\text { \% } \\
\text { removed }\end{array}$ & $\begin{array}{l}\text { Initial } \\
\mathrm{mg} / \mathrm{L}\end{array}$ & $\begin{array}{l}\text { Final } \\
\mathrm{mg} / \mathrm{L}\end{array}$ & $\%$ removed \\
\hline & \multicolumn{2}{|c|}{ Phosphate } & & Nitrate & & \\
\hline \multicolumn{7}{|c|}{ Klebsiella sp. } \\
\hline $25^{\circ} \mathrm{C}$ & 191.6 & 170.8 & 10.8 & 256.1 & 23.9 & 90.7 \\
\hline $30^{\circ} \mathrm{C}$ & 191.6 & 77.1 & 59.8 & 256.9 & 11.2 & 95.6 \\
\hline $35^{\circ} \mathrm{C}$ & 191.6 & 83.0 & 56.7 & 256.9 & 7.0 & 97.3 \\
\hline $40^{\circ} \mathrm{C}$ & 191.6 & 85.2 & 55.6 & 256.9 & 18.4 & 92.9 \\
\hline \multicolumn{7}{|c|}{ Lysinibacillussp. } \\
\hline $25^{\circ} \mathrm{C}$ & 191.5 & 191.6 & -0.1 & 256.3 & 197.0 & 23.1 \\
\hline $30^{\circ} \mathrm{C}$ & 191.6 & 94.2 & 50.8 & 255.4 & 252.9 & 1.0 \\
\hline $35^{\circ} \mathrm{C}$ & 191.6 & 104.9 & 45.2 & 256.1 & 239.2 & 6.6 \\
\hline $40^{\circ} \mathrm{C}$ & 191.6 & 168.8 & 11.9 & 255.2 & 249.6 & 2.2 \\
\hline \multicolumn{7}{|c|}{ Pseudomonas sp. } \\
\hline $25^{\circ} \mathrm{C}$ & 191.5 & 190.8 & 0.4 & 267.7 & 11.5 & 91.6 \\
\hline $30^{\circ} \mathrm{C}$ & 191.5 & 78.6 & 59.0 & 268.4 & 20.8 & 92.3 \\
\hline $35^{\circ} \mathrm{C}$ & 191.5 & 88.5 & 53.8 & 256.0 & 18.6 & 92.8 \\
\hline $40^{\circ} \mathrm{C}$ & 191.5 & 101.5 & 47.0 & 266.8 & 260.9 & 2.2 \\
\hline \multicolumn{7}{|c|}{ Staphylococcus sp. } \\
\hline $25^{\circ} \mathrm{C}$ & 191.5 & 186.2 & 2.7 & 256.3 & 33.9 & 86.8 \\
\hline $30^{\circ} \mathrm{C}$ & 191.5 & 93.4 & 51.2 & 256.9 & 21.4 & 91.7 \\
\hline $35^{\circ} \mathrm{C}$ & 191.6 & 94.6 & 50.6 & 256.0 & 27.6 & 89.2 \\
\hline $40^{\circ} \mathrm{C}$ & 191.5 & 121.0 & 36.8 & 255.4 & 236.1 & 7.6 \\
\hline
\end{tabular}

The trend in $\mathrm{pH}$ in the presence of the test bacterial isolates during the nutrient removal study is displayed in Table 2. As shown in the Table, there was a general increase in $\mathrm{pH}$ with incubation time. This trend was irrespective of the bacterial species or the incubation temperature. There seemed to be a general gradual increase in $\mathrm{pH}$ from 5.9 towards neutral and alkalinity. In presence of the isolates, $\mathrm{pH}$ at the end of incubation was observed to range from 6.8 to 7.3 , from 6.2 to 7.2 , from 6.4 to 7.6 , and from 6.5 to 6.6 , in the presence of the Klebsiellasp., Lysinibacillussp., Pseudomonas sp., and Staphylococcus sp., respectively (Table 2). 
Table 2. $\mathrm{pH}$ variations at the different temperatures in presence of the test bacterial species

\begin{tabular}{lllll}
\hline Time & $\mathbf{2 5}^{\circ} \mathbf{C}$ & $\mathbf{3 0}^{\circ} \mathbf{C}$ & $\mathbf{3 5}^{\circ} \mathbf{C}$ & $\mathbf{4 0}^{\circ} \mathbf{C}$ \\
\hline Klebsiellasp. & & & & \\
Oh & 5.9 & 6.6 & 5.9 & 6.6 \\
24h & 6.4 & 6.5 & 6.4 & 6.4 \\
48h & 6.9 & 6.6 & 6.9 & 6.6 \\
72h & 7.4 & 7.0 & 7.4 & 6.7 \\
96h & 7.3 & $7.3)$ & 7.3 & 6.8 \\
Lysinibacillus sp. & & & & \\
Oh & 5.9 & 6.5 & 5.9 & 6.6 \\
24h & 6.3 & 6.3 & 6.3 & $6.4)$ \\
48h & 6.7 & 6.3 & 6.7 & 6.3 \\
72h & 7.1 & 6.4 & 7.1 & 6.2 \\
96h & 7.2 & 6.5 & 7.2 & 6.2 \\
Pseudomonas sp. & & & & \\
Oh & 5.9 & 6.5 & 5.9 & 6.6 \\
24h & 6.3 & 6.3 & 6.3 & 6.4 \\
48h & 6.9 & 6.4 & 7.0 & 6.3 \\
72h & 7.5 & 6.6 & 7.5 & 6.4 \\
96h & 7.6 & 6.9 & 7.6 & 6.4 \\
Staphylococcus sp. & & & & \\
Oh & 5.9 & 6.5 & 5.9 & 6.6 \\
24h & 6.2 & 6.3 & 6.2 & 6.6 \\
48h & 6.4 & 6.4 & 6.4 & 6.6 \\
72h & 6.5 & 6.5 & 6.5 & 6.5 \\
96h & 6.6 & 6.5 & 6.6 & 6.6 \\
\hline
\end{tabular}

All values are average of triplicate analysis.

As shown in Table 3, growth rates of the test bacterial species during the nutrient removal studies were observed to range from $1.871 \mathrm{~d}^{-1}$ to $1.987 \mathrm{~d}^{-1}, 1.839 \mathrm{~d}^{-1}$ to $1.970 \mathrm{~d}^{-1}$, from 1.850 $\mathrm{d}^{-1}$ to $1.942 \mathrm{~d}^{-1}$ from and from $1.837 \mathrm{~d}^{-1}$ to $1.942 \mathrm{~d}^{-1}$ in the presence of the Klebsiellasp., Lysinibacillussp., Pseudomonas sp. and Staphylococcus sp., respectively. In all the bacterial species, highest growth rates were observed at $25^{\circ} \mathrm{C}$ (Table 3).

In the present study, the carbon source was acetate. The choice of acetate was deliberate. Previous investigators have indicated acetate as a preferred carbon source during nutrient removal studies $[18,19]$. The study was carried out using four bacterial isolates. The test bacterial species were isolated from domestic wastewater sources and have previously been implicated as having ability to degrade dietary oil substrate in wastewater [20]. The choice was of the isolates was deliberate. This was because since they have been reported to have oil degradation ability, exploring their efficiency in the removal of eutrophic nutrients in wastewater could reveal their bioremediation potential.

The study showed optimum temperature for nutrient removal by the test isolates to vary for phosphate and nitrate removals. The observation for phosphate indicates some measure of removals in presence of all the test isolate at temperature range of $30^{\circ} \mathrm{C}$ and $35^{\circ} \mathrm{C}$. In the case of nitrate, optimum range for removal in presence of the three isolates (Klebsiella sp. Pseudomonas sp. and Staphylococcus sp.) that displayed uptake efficiencies was $25^{\circ} \mathrm{C}$ to $35^{\circ} \mathrm{C}$. In a study on the effect of temperature on the nutrient removal efficiency of three 
protozoan isolates, $25^{\circ} \mathrm{C}$ was indicated as the optimum temperature for phosphate and nitrate removal in activated sludge mixed liquor [21].

Table 3. Growth rate $\left(d^{-1}\right)$ of the test bacterial species at the different temperatures during the nutrient removal studies

\begin{tabular}{|c|c|c|c|c|}
\hline Time & $25^{\circ} \mathrm{C}$ & $30^{\circ} \mathrm{C}$ & $35^{\circ} \mathrm{C}$ & $40^{\circ} \mathrm{C}$ \\
\hline \multicolumn{5}{|c|}{ Klebsiella sp } \\
\hline $24 \mathrm{~h}$ & 1.543 & 1.952 & 1.905 & 1.856 \\
\hline $48 \mathrm{~h}$ & 1.954 & 1.958 & 1.910 & 1.862 \\
\hline $72 \mathrm{~h}$ & 1.974 & 1.958 & 1.925 & 1.868 \\
\hline $96 \mathrm{~h}$ & 1.987 & 1.967 & 1.927 & 1.871 \\
\hline \multicolumn{5}{|c|}{ Lysinibacillus sp } \\
\hline $24 \mathrm{~h}$ & 1.940 & 1.832 & 1.893 & 0.000 \\
\hline $48 \mathrm{~h}$ & 1.951 & 1.834 & 1.896 & 1.933 \\
\hline $72 \mathrm{~h}$ & 1.961 & 1.834 & 1.898 & 1.933 \\
\hline $96 \mathrm{~h}$ & 1.970 & 1.839 & 1.903 & 1.935 \\
\hline \multicolumn{5}{|c|}{ Pseudomonas sp } \\
\hline $24 \mathrm{~h}$ & 1.936 & 1.837 & 1.830 & 1.857 \\
\hline $48 \mathrm{~h}$ & 1.939 & 1.839 & 1.841 & 1.858 \\
\hline $72 \mathrm{~h}$ & 1.940 & 1.846 & 1.845 & 1.859 \\
\hline $96 \mathrm{~h}$ & 1.942 & 1.853 & 1.850 & 1.860 \\
\hline \multicolumn{5}{|c|}{ Staphylococcus sp } \\
\hline $24 \mathrm{~h}$ & 1.936 & 1.835 & 1.896 & 0.000 \\
\hline $48 \mathrm{~h}$ & 1.939 & 1.836 & 1.898 & 1.856 \\
\hline $72 \mathrm{~h}$ & 1.940 & 1.836 & 1.900 & 1.857 \\
\hline $96 \mathrm{~h}$ & 1.942 & 1.837 & 1.903 & 1.859 \\
\hline
\end{tabular}

Despite the fact that temperature is indicated as one of the factors that affect the growth and metabolic processes of microorganisms, there seems to be contradictory reports on its effects on nutrient removal in presence of difference organisms [22, 23]. It is also specified that temperature is a key parameter which affects reaction kinetics and performance of biological nutrient removal systems. There are also, conflicting observations on the role of temperature on enhanced biological nutrient removal systems [24, 25]. It is suggested that the inconsistencies in temperature findings among different investigators may be as a result of varying substrates, diverse system configurations, use of different analytical techniques and the application of different operational conditions, hence making it challenging to compare results $[3,26]$.

An observation in this study was that although maximum growth rates were obtained at incubation temperature of $25^{\circ} \mathrm{C}$ by the different isolates during the nutrient removal studies, this was not the optimum temperature for nutrient removal by the majority of the isolates. It is indicated that while there may be optimal ranges temperature for growth by different organisms, such optimal ranges may not necessarily be the same for nutrient removal [27, 28]. Although all the temperatures investigated during the course of this study were within the mesophilic ranges, available reports suggests that biological treatment activity is reported to accelerate in warm temperatures and to slow in cool temperatures, but extremely hot or cold temperatures can stop treatment processes [29]. According to Mamais and Jenkins [30], the optimum operating temperature for an efficient biological nutrient process should range between $28^{\circ} \mathrm{C}$ and $30^{\circ} \mathrm{C}$. 
In the by Brdjanovic [31], during the investigation of the short-term effects of temperature on phosphate removal in biological systems, an optimum temperature $20^{\circ} \mathrm{C}$ was observed. Similarly, Jones and Stephenson [32] indicated that although a temperature of $30^{\circ} \mathrm{C}$ was observed as optimum for phosphate removal in wastewater, remarkable removals were also observed at extreme temperatures of $5^{\circ} \mathrm{C}$ and $40^{\circ} \mathrm{C}$.

The study revealed a slow but steady increase in $\mathrm{pH}$ throughout the period of incubation, a trend that was observed irrespective of the isolate used for investigation or incubation temperature. Steady increases in $\mathrm{pH}$ during nutrient removal studies have been reported by earlier workers $[21,28]$. The increase in $\mathrm{pH}$ during biological nutrient removal is suggested to be due to the utilization of residual oxygen as a result of nutrient uptake, which simultaneously consumes $\mathrm{H}^{+}$in reactors [28].

\section{CONCLUSION}

The study which investigated the effect of temperature on the nutrient removal ability of the test bacterial species was able to reveal the following:

- The Optimum temperatures for nutrient removal were observed to range from $30^{\circ} \mathrm{C}$ to $35^{\circ} \mathrm{C}$ for phosphate removal and $25^{\circ} \mathrm{C}$ to $35^{\circ} \mathrm{C}$ for nitrate removal

- The optimum temperature for the highest growth rate was not observed to be the optimum temperature for nutrient removal by the majority of the test bacterial species

- All the test bacterial species showed remarkable nitrate removal were efficient at incubation temperature of $25^{\circ} \mathrm{C}$ to $35^{\circ} \mathrm{C}$. At $40^{\circ} \mathrm{C}$, only the Klebsiella sp still exhibited nitrate removal ability.

- Between $30^{\circ} \mathrm{C}$ and $35^{\circ} \mathrm{C}$, all the four isolates showed remarkable phosphate removal

- During nutrient removal studies in presence of the test bacterial species, there were consistent but slow increases in $\mathrm{pH}$ of the wastewaters.

The study was able to provide relevant information on the effect of temperature on the nutrient removal efficiency of the isolates in synthetic wastewaters.

\section{COMPETING INTERESTS}

Authors have declared that no competing interests exist.

\section{REFERENCES}

1. EPA. Onsite wastewater treatment systems manual. 2002: EPA/625/R-00/008/2002. Available from http:// www.epa.gov/owmitnet/mtbfact.htm

2. Becker EW. Microalgae: Biotechnology and Microbiology. Cambridge University Press, Cambridge; 1994.

3. Larsdotter K. Microalgae for phosphorus removal from wastewater in a Nordic climate.A Doctoral Thesis from the School of Biotechnology, Royal Institute of Technology, Stockholm, Sweden; 1994.

4. De-Bashana LE, Yoav BB. Recent advances in removing phosphorus from wastewater and its future use as fertilizer (1997-2003). Water Research. 2004; 38(19):4222-4246. 
5. Ramothokang TR, Simelane SC, Bux F. Biological nitrogen and phosphorus removal by filamentous bacteria in pure culture. Water Institute of South Africa (WISA) Biennial Conference, Durban, South Africa; 2006.

6. Srivastava NK, Majumder CB. Novel biofiltration methods for the treatment of heavy metals from industrial wastewater. Journal of Hazardous Materials. 2008:151(1):1-8.

7. Sathasivan A. Biological Nutrient removal processes for wastewater treatment, water and wastewater treatment technologies. Encyclopedia of Life Support Systems (EOLSS); 2009.

8. [8] Sarioglu M. Biological phosphorus removal in a sequencing batch reactor by using pure cultures. Process Biochemistry. 2005:40:1599-1603.

9. Tchobanoglous G, Burton FL, Stensel HD. Wastewater Engineering: Treatment and Reuse. Metcalf \& Eddy, Inc., 4th Edition, McGraw-Hill Education; 2003.

10. Jalal KCA, ZahangirAlam MD, Matin WA, Kamaruzzaman BY, Akbar J, ToffazelH.Removal of nitrate and phosphate from municipal wastewater sludge by Chlorella vulgaris, SpirulinaplatensisandScenedesmusquadricauda. IIUM Engineering Journal. 2011;12(4):125-132

11. Bitton G. Wastewater Microbiology. John Wiley \& Sons, inc., Publication; USA. 1994;3:63-65.

12. Momba MNB, Cloete TE. The relationship of biomass to phosphate uptake by Acinetobacter junii activated sludge mixed liquor. Water Research. 1996:30:364-370

13. Mbewele L. Microbial phosphorus removal in wastewater stabilization pond.A Licentiate Thesis from the School of Biotechnology: A Royal Institute of Technology, Albanova, Stockholm, Sweden; 2006

14. Krishnaswamy U, Muthuchamy M, Perumalsamy L. Biological removal of phosphate from synthetic wastewater using bacterial consortium. Iranian Journal of Biotechnology. 2011:9(1):37-49.

15. Jackson LM, Myers JE.Free-water surface wetlands treating NPR-3 produced water year No. 2. Work Performed Under Rocky Mountain Oilfield Testing Center (RMOTC) CRADA No. 2001-001; 2002.

16. APHA. 2001. Standard Methods for the Examination of Water and Wastewater, $22^{\text {nd }}$ edition. APHA, Washington D.C.; 2012.

17. Hammer O, Harper DAT, Ryan PD. 2001. PAST: Paleontological statistics software package for education and data analysis. Palaeontologia Electronica. 2001:4(1):9. http://palaeo-electronica.org/2001 1/past/issue1 01.htm

18. Kargi F, Uygur, A. Effect of carbon source on biological nutrient removal in a sequencing batch reactor. Bioscience Technology. 2003:89(1):89-93.

19. Akpor OB, Momba MNB, OkonkwoJO..Protozoan biomass relation to nutrient and chemical oxygen demand removal in activated sludge mixed liquor. Biotechnology Journal. 2008:3:1083-1087.

20. Odeyemi AT, Aderiye BI, Bamidele OS. Lipolytic activity of some strains of Klebsiella, Pseudomonas and Staphylococcus spp. from restaurant wastewater and receiving stream.Journal of Microbiology Research. 2013:3(1):43-52.

21. Akpor OB, Momba MNB, Okonkwo JO. The effects of $\mathrm{pH}$ and temperature on phosphate and nitrate removal by wastewater protozoa.African Journal of Biotechnology. 2008:7(13):2221-2226.

22. Mino T. Review: microbial selection of polyphosphate-accumulating bacteria in activated sludge wastewater treatment processes for enhanced biological removal. Biochemistry. 2000:63(3):341-348.

23. Seviour RJ, Mino T, Onuki M. The microbiology of biological phosphorus removal in activated sludge systems. FEMS Microbiological Review. 2003;27:99-127. 
24. Erdal UG, Erdal ZK, Randall CW. A thermal adaptation of bacteria to cold temperatures in an enhanced biological phosphorus removal system. Water Science and Technology. 2003:47(11):123-128.

25. Thongchai $P$, Aspiradee $D$, Jin A. Effect of temperature shock on activities of phosphorus-accumulating organisms. Science Asia. 2003:29:365-370.

26. Wentzel MC. Future of Nutrient Removal in South Africa. WISA Nutrient Removal Technical Division, $1^{\text {st }}$ open meeting, South Africa; 1991.

27. Sabalowsky AR. An investigation of the feasibility of nitrification and denitrification of a complex industrial wastewater with high seasonal temperatures.Master's Thesis from Virginia Polytechnic Institute and State University. Blacksburg; 1999.

28. Saito T, Brdjanovic D, van Loosdrecht MCM. Effect of nitrite on phosphate uptake by phosphate accumulating organisms.Water Research. 2004:3:3760-3768.

29. Metcafe X, Eddy X. Wastewater Engineering: Treatment and Reuse. In: Wastewater Engineering, Treatment, Disposal and Re-use. Techobanoglous G, Burton FL, Stensel HD (eds), Tata McGraw-Hill Publishing Company Limited, $4^{\text {th }}$ edition. New Delhi, India; 2003.

30. Mamais D, Jenkins D. The effects of MCRT and temperature on enhanced biological phosphorus removal. Water Science and Technology. 1992;26(5-6):955-965

31. Brdjanovic D, Hooijmans CM, van Loosdrecht MCM, Alaerts GJ, Heeijen JJ. The dynamic effect of potassium limitation on biological phosphorus removal. Water Research. 1996:30(1):303-313.

32. Jones $M$, Stephenson $T$. The effect of temperature on enhanced biological phosphorus removal. Environmental Technology. 1996;17:965-976.

(C) 2014 Akpor et al.; This is an Open Access article distributed under the terms of the Creative Commons Attribution License (http://creativecommons.org/licenses/by/3.0), which permits unrestricted use, distribution, and reproduction in any medium, provided the original work is properly cited

Peer-review history:

The peer review history for this paper can be accessed here: http://www.sciencedomain.org/review-history.php?iid=354\&id=8\&aid=2857 